\title{
Impact of Stocking Rate and Rainfall on Sheep Performance in a Desert Steppe
}

\author{
Zhongwu Wang, ${ }^{1}$ Shuying Jiao, ${ }^{4}$ Guodong Han, ${ }^{2}$ Mengli Zhao, ${ }^{2}$ Walter D. Willms, ${ }^{5}$ Xiying Hao, ${ }^{6}$ \\ Jian'an Wang, ${ }^{3}$ Haijun Din, ${ }^{3}$ and Kris M. Havstad
}

Authors are ${ }^{1}$ Lecturer, ${ }^{2}$ Professors, and ${ }^{3}$ Graduate Students, College of Ecology and Environmental Science, Inner Mongolia Agricultural University, Hohhot, Inner Mongolia, P. R. China 010018; ${ }^{4}$ Lecturer, College of Resources and Environment, Shandong Agricultural University, Tai'an, Shandong, P. R. China 271018; ${ }^{5}$ Range Scientist and ${ }^{6}$ Soil Scientist, Agriculture and Agri-Food Canada, PO Box 3000, Lethbridge, Alberta, Canada T1J 4B1; and ${ }^{7}$ Supervisory Scientist, USDA-ARS Jornada Experimental Range MSC 3JER, NMSU, Box 30003, Las Cruces, NM 88003, USA.

\begin{abstract}
Livestock performance is a critical indicator of grassland production systems and is influenced strongly by precipitation and stocking rates. However, these relationships require further investigation in the arid Desert Steppe region of northeastern China. We employed a randomized complete block design with three replications and four grazing treatments (nongrazed exclosure [Control]), lightly grazed [LG], moderately grazed [MG], and heavily grazed [HG]) by sheep in a continuously grazed system (June to November), to test the effect of stocking rate on sheep performance. The planned stocking rates were $0,0.15,0.30$, and 0.45 sheep $\cdot \mathrm{ha}^{-1} \cdot \mathrm{mo}^{-1}$, for the control, LG, MG, and HG treatments, respectively. However, actual stocking rates were calculated for each paddock in each year based on a 50-kg sheep equivalent (SE). Annual net primary production (ANPP) was determined at peak standing crop in August 2004 to 2008. Live weight gain was determined for the summer and fall periods, as well as the total grazing period, in each year. ANPP decreased with increasing stocking rate, and daily live weight gain per head decreased linearly with increasing stocking rates over the total grazing period but in a quadratic manner over the summer period with a plateau at the lower rates. Maximum sheep production per unit area over the total grazing season occurred at about $2 \mathrm{SE} \mathrm{ha}^{-1}$ for about a 5 -mo grazing period, but individual gains per sheep were predicted to decline after about $1 \mathrm{SE} \mathrm{ha}^{-1}$ presumably because of forage limitations. However, in order to achieve stable annual production, we recommend that the Desert Steppe be grazed at about $0.77 \mathrm{SE} \mathrm{ha}{ }^{-1}$ for a 5 -mo period $\left(0.15 \mathrm{SE} \mathrm{ha}^{-1} \cdot \mathrm{mo}^{-1}\right)$. This estimate is based on published grazing strategies that consider an average ANPP with a recommended utilization rate of $30 \%$.
\end{abstract}

\section{Resumen}

El rendimiento del ganado es un indicador crucial de los sistemas de producción en los pastizales, y está vinculado definitivamente a la precipitación y a la carga animal. Sin embargo, esta relación requiere más investigación en la región árida de la estepa del desierto del noreste de China. Se utilizó un diseño de bloques completamente al azar con tres repeticiones y cuatro tratamientos de pastoreo (nopastoreo [Control], pastoreo ligero [PL], pastoreo moderado [PM] y pastoreo alto [PA] con ovejas en un sistema de pastoreo continuo (de Junio a Noviembre), para examinar el efecto de la carga animal en el rendimiento de las ovejas. La carga animal planeada fue 0 , $0.15,0.30$, y 0.45 ovejas $\cdot \mathrm{ha}^{-1} \cdot \mathrm{mo}^{-1}$ para los tratamientos de control, PL, PM, y PA respectivamente. Sin embargo, la carga animal definitiva se calculó para cada potrero en cada año basándose en la equivalencia de una oveja (SE) de $50 \mathrm{~kg}$. La producción anual primaria (ANPP) se determinó al final de la época de crecimiento en Agosto, del 2004 y del 2008. La ganancia de peso se obtuvo para los periodos del verano y del otoño, así como para el periodo total de pastoreo, en cada año. La ANPP disminuyó al incrementar la carga animal y la ganancia por día por cabeza disminuyó linealmente con el incremento de la carga animal en el periodo total de pastoreo. Sin embargo, lo hizo de una forma cuadrática durante el periodo del verano siendo estable en las carga más bajas. La producción máxima de las ovejas por unidad de área para la estación total de pastoreo ocurrió alrededor de $2 \mathrm{SEha}^{-1}$ en aproximadamente 5 meses de pastoreo. Se pudo predecir que las ganancias individuales disminuirían después de $1 \mathrm{SE} \mathrm{ha}^{-1}$ debido a las limitaciones del forraje. Sin embargo, para poder llevar a cabo una producción anual estable, recomendamos que la estepa del desierto se pastoree alrededor de $0.77 \mathrm{SEha}{ }^{-1}$ por un periodo de 5 meses $\left(0.15 \mathrm{SE} \mathrm{ha}^{-1} \cdot \mathrm{mo}^{-1}\right)$. Esta estimación se basa en las publicaciones de las estrategias de pastoreo que consideran una ANPP con una utilización recomendada de un 30\%.

Key Words: live weight gain, grazing management, Inner Mongolia, optimal stocking rate, Stipa breviflora Griseb

Research was funded by the National Basic Research Program of China (2007CB106800), National Science \& Technology Supporting Program during the 11th Five-Year Plan (2008BAD95B03), National Natural Science Foundation of China (30860060, 31070413), National Public Benefit (Agricultural) Research Foundation of China (200903060, 201003019), and Inner Mongolia Science and Technological Committee, China. We gratefully acknowledge support from the China Scholarship Council, Ministry of Education, P. R. China, and the laboratory of Lethbridge Research Centre, Agriculture and Agri-Food Canada.

Zhongwu Wang and Shuying Jiao made an equal contribution to this paper.

Correspondence: Guodong Han, College of Ecology and Environmental Science, Inner Mongolia Agricultural University, Hohhot, Inner Mongolia, P. R. China 010018. Email: grasslandkeylab@ gmail.com

Manuscript received 26 March 2009; manuscript accepted 14 January 2011.

\section{INTRODUCTION}

There is an extensive history of research examining relationships between stocking rate and livestock production (Orr and Newton 1984; Common et al. 1993; Ash and Smith 1996; Hart and Ashby 1998; Han et al. 2000; Derner and Hart 2005). Typically, live weight gain per animal decreases and gain per area increases as stocking rate increases until stocking becomes excessive and gains per unit area decline (Hatch and Tainton 1997). Live weight gain had been used as an important indicator for predicting optimal stocking rates in grassland management (Hart et al. 1988b; Han et al. 2000). It has been 
Table 1. Precipitation distribution over the growing season and total annual precipitation in each year of the grazing study of a Desert Steppe community in Inner Mongolia.

\begin{tabular}{|c|c|c|c|c|c|c|c|c|}
\hline Year & April & May & June & July & August & September & $\begin{array}{l}\text { April to } \\
\text { September }\end{array}$ & Annual \\
\hline & - & 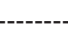 & ---- & - & 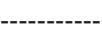 & 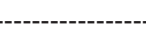 & --- & -- \\
\hline 2004 & 12 & 72 & 32 & 51 & 68 & 12 & 247 & 253 \\
\hline 2005 & 2 & 30 & 0.3 & 22 & 86 & 16 & 156 & 157 \\
\hline 2006 & 1 & 24 & 24 & 42 & 49 & 19 & 159 & 161 \\
\hline 2007 & 3 & 13 & 31 & 37 & 23 & 27 & 134 & 162 \\
\hline 2008 & 1 & 5 & 45 & 69 & 56 & 35 & 211 & 231 \\
\hline Mean & 4 & 29 & 26 & 44 & 56 & 22 & 181 & 193 \\
\hline
\end{tabular}

generally observed that average daily gains decline exponentially beyond an optimum stocking rate (Ackerman et al. 2001).

Optimal stocking rates for any given landscape will vary between years, ecological sites types, and class of grazing animals (McCollum 1993). A biologically optimum stocking rate can be estimated from an animal production curve, but this predicted optimum is only a guide that must be adjusted in response to actual management practices (Wilson and Macleod 1991). An economically based optimum stocking rate requires known fixed and variable costs and can be calculated from a relationship between production per head and production per unit area (McCollum 1993; Ash and Smith 1996). The relationships between live weight gain per head and per hectare are pivotal to conceptual development of optimal stocking rates.

Generally, rainfall is a key driving variable for grassland vegetation, soil, and livestock productivity (Orr 1980; Fynn and O'Connor 2000; Ursino and Contarini 2006). In arid and semiarid grasslands, rainfall amount and pattern (season and intensity) have a direct influence on primary production (Milchunas et al. 1994; Bates et al. 2006) and have an indirect effect on livestock production (Yu et al. 2004).

Rainfall can account for most of the temporal variation in animal weight gain (Fynn and O'Connor 2000). Within the Desert Steppe of Inner Mongolia, over $60 \%$ of annual precipitation occurs during a 6-mo period from April to September. This is also the key period for livestock grazing on the Inner Mongolian rangelands. Therefore, an understanding of the relationships between stocking rate and primary or secondary production, and the influence that precipitation may have on it, is important for sustainable grassland management. To clarify those relationships for the Desert Steppe, we conducted a study to determine the effect of stocking rate and rainfall on sheep production in order to provide an experimental basis for stocking rate recommendations within the Desert Steppe of Inner Mongolia.

\section{MATERIALS AND METHODS}

\section{Site Description}

The experiment was conducted from June 2004 to November 2008 in Siziwang Banner, Inner Mongolia, China $\left(41^{\circ} 46^{\prime} 43.6^{\prime \prime} \mathrm{N}\right.$, $111^{\circ} 53^{\prime} 41.7^{\prime \prime}$; elevation $1456 \mathrm{~m}$ ) in a Desert Steppe community. The climate of this site is classified as continental with a mean annual precipitation of $193 \mathrm{~mm} \mathrm{yr}^{-1}$ and mean annual temperature of $3.4^{\circ} \mathrm{C}$. The climate is very dry and windy in spring with high ambient air temperatures during the summer months. The majority of precipitation occurs from April to September. The frost-free period is $175 \mathrm{~d}$. The soil is Kastanozem (FAO soil classification) with a sandy loam texture. The dominant plant species of the study area are Stipa breviflora Griseb., Artemisia frigida Willd., and Cleistogenes songorica (Roshev.) Ohwi, while the average vegetation height is about $5 \mathrm{~cm}$ with a canopy cover ranging from $17 \%$ to $20 \%$. The vegetation and soil characteristics are shown in Table 1.

The majority of the experimental site was degraded due to overgrazing in the past $15+\mathrm{yr}$ prior to the onset of our grazing experiment. The site had been grazed by sheep year-long at a stocking rate of $<0.08$ sheep $\cdot \mathrm{ha}^{-1} \cdot \mathrm{mo}^{-1}$ prior to 1988 . Stocking rate increased steadily after 1988 and reached about 0.5 sheep $\cdot \mathrm{ha}^{-1} \cdot \mathrm{mo}^{-1}$ at the time the experiment began in 2004 .

\section{Experimental Design}

In 2004, 12 paddocks were fenced along a gradient of increasing grazing pressure that had previously been imposed for $2 \mathrm{yr}$ as part of a grazing experiment. Therefore, we employed a randomized complete block design of four planned stocking rate treatments and three blocks. The stocking rates were nongrazed (Control), lightly grazed (LG), moderately grazed (MG), and heavily grazed (HG) representing $0,0.15,0.30$, and 0.45 sheep $\cdot \mathrm{ha}^{-1} \cdot \mathrm{mo}^{-1}$, respectively. The treatments randomly assigned to the paddocks at the start of the study in 2004.

In the spring of 2004, 72 sheep from the same cohort (2-yrold in 2004, Mongolian wethers) were randomly allocated to the 12 paddocks according to plan. Their average initial weights (mean $\pm \mathrm{SE}$ ) were $34.9 \pm 0.3 \mathrm{~kg}, 42.2 \pm 0.4 \mathrm{~kg}$, $40.6 \pm 0.5 \mathrm{~kg}, 33.3 \pm 0.7 \mathrm{~kg}$, and $49.1 \pm 1.0$ for 2004, 2005, 2006, 2007, and 2008, respectively (Table 2). Two cohorts of sheep were used: one cohort from 2004 through 2006, and a second cohort from 2007 and 2008.

Seasonal grazing was planned for 6 mo during the period June to November in each year. The actual grazing period in different years is fluctuated depending on the available forage from year to year. The daily grazing schedule was from 06:00 to 18:00. The sheep were penned each evening in a separate enclosure away from the experimental site. Water was provided twice per day (at early morning and dusk), and salt was offered ad libitum in the paddocks over the entire grazing period. From December through May each year, all experimental sheep were kept in the enclosure and supplied with hay, corn stover, and grain at levels that met their maintenance energy requirements. 
Table 2. Initial vegetation conditions as measured in moveable cages in August 2004, within experimental paddocks, and initial weights of sheep used in each year of the trial.

\begin{tabular}{|c|c|c|c|c|c|c|c|c|}
\hline & \multicolumn{3}{|c|}{ Initial vegetation condition in 2004} & \multicolumn{5}{|c|}{ Sheep initial weight of each year $(\mathrm{kg})$} \\
\hline & $\begin{array}{l}\text { Canopy } \\
\text { (\% cover) }\end{array}$ & $\begin{array}{c}\text { ANPP } \\
\left(\mathrm{kg} \cdot \mathrm{ha}^{-1}\right)\end{array}$ & $\begin{array}{l}\text { Perennial grass } \\
\text { ( } \% \text { of ANPP) }\end{array}$ & 2004 & 2005 & 2006 & 2007 & 2008 \\
\hline Control $^{1}$ & 21 & 1102 & 20 & - & - & - & - & - \\
\hline LG & 22 & 907 & 29 & 36 & 41 & 42 & 34 & 50 \\
\hline$M G$ & 18 & 1152 & 18 & 36 & 44 & 43 & 32 & 48 \\
\hline$H G$ & 18 & 913 & 25 & 34 & 40 & 39 & 34 & 50 \\
\hline Mean $^{2}$ & & & & $35 \mathrm{a}$ & $43 \mathrm{~b}$ & $41 \mathrm{~b}$ & 33 a & $49 \mathrm{c}$ \\
\hline SEM & 2.1 & 10.1 & 0.04 & 1.4 & & & & \\
\hline Effect & ----- & --------- & bility---------- & ------ & & & & \\
\hline Treatment $(\mathrm{T})$ & 0.19 & 0.20 & 0.29 & 0.17 & & & & \\
\hline Year (Y) & & & & $<0.01$ & & & & \\
\hline $\mathrm{T} \times \mathrm{Y}$ & & & & 0.41 & & & & \\
\hline
\end{tabular}

${ }^{1} \mathrm{LG}, \mathrm{MG}$, and $\mathrm{HG}$ represent low, moderate, and heavy stocking rates, respectively.

${ }^{2}$ Means in a row having the same letter are not different $(P>0.05)$.

\section{Measurements}

Annual net primary production (ANPP) was determined in August of each year by harvesting a single $1-\mathrm{m}^{2}$ quadrate inside each of five portable cages $(1.5 \times 1.5 \mathrm{~m})$ that were established in each paddock before grazing began in spring. Before harvesting the quadrate, the canopy of all plants was determined visually as a proportion of ground cover. Available forage during the grazing season was estimated monthly by harvesting at ground level $150.1-\mathrm{m}^{2}$ paddocks in 2004, 2005, and 2006 and $101.0-\mathrm{m}^{2}$ quadrates in 2007 and 2008 outside the portable cage. These estimates were averaged for grazing period and represented the average forage available to the sheep over that period. The cages and all quadrates were located randomly and moved after they were harvested. Harvested biomass was separated by species, oven-dried at $65^{\circ} \mathrm{C}$ for $48 \mathrm{~h}$, and then weighed. Available forage was calculated as the sum of all species. Herbage allowance was calculated on the basis of a sheep equivalent (SE) defined as a $50-\mathrm{kg}$ animal and expressed as available forage $\mathrm{SE}^{-1} \cdot \mathrm{ha}^{-1}$.

Live weight gain per animal and per hectare were determined for the summer and fall periods, as well as the total grazing period, in each year. The sheep were weighed on the first and last days of the total grazing period as well as once near the beginning of fall to yield a summer and fall grazing period. In 2005 grazing was terminated in late summer because of dry conditions. As a result the gains representing the summer period were equivalent to the total period while the fall period was absent. In 2006, the sheep were not weighed in midseason, which prevented calculating spring and fall estimates. Gains per sheep were calculated as the weight difference between two dates and expressed as daily weight gain.

A micro-weather station was located adjacent to the experimental site in 2003. Precipitation was measured at a nearby meteorological station (GroWeather ${ }^{\circledR}$ software version 1.2, Davis Instruments Corporation, Vernon Hills, IL) located about $1 \mathrm{~km}$ from the grazing study.

\section{Statistical Analyses}

The effects of planned stocking rate, year, and their interaction on ANPP and sheep weight gains were analyzed using a mixed model (MIXED procedure; SAS Institute 2008) with replications and replication $\times$ stocking rate as random effects. The residuals of all analyses were tested for normality using the UNIVARIATE procedure of SAS (SAS Institute 2008). Where necessary, outliers were either removed or the data was transformed using the logarithmic transformation. Significant differences among means were detected using the least significant difference test when the treatment effects were significant $(P<0.05)$.

In order to account for changing animal weights among years, and weight differences among treatments within years, we calculated a revised stocking rate for each paddock based on the sheep equivalent for a $50-\mathrm{kg}$ animal at the beginning of each grazing season. Models were developed that best explained the relationship of average daily gain (ADG) to the adjusted stocking rate using TableCurve 2D 5.01 (SYSTAT Software 2008). The resulting model was used to calculate the relationship of stocking rate on ADG $\cdot \mathrm{ha}^{-1}$. The relationship of ADG to allowable herbage mass was fit to the model: $\mathrm{ADG}=a(1-[\exp \{-$ allowable forage $\}])$ using the NLIN procedure (SAS Institute 2008); here $a$ is the plateau that represents the point at which ADG is unresponsive to additional allowable forage, and the exponent defines the slope of that relationship.

Regression analyses (procedure REG; SAS Institute 2008) were used to determine the relationship between forage production and rainfall. For these analyses we used the April to July precipitation totals, in favor of April to September or May to September, as they provided the best fit as measured by their correlation coefficient. Simple regression coefficients were determined by replicate for each treatment. Their coefficients and intercepts were used to test the effects of planned stocking rates on the relationship between forage production and rainfall.

\section{RESULTS}

\section{Precipitation}

Most of the annual precipitation occurred from April to September with amounts during the grazing period in 2004, 2005, 2006, 2007, and 2008, accounting for 98\%, 99\%, 99\%, $81 \%$, and $92 \%$ of total annual precipitation, respectively. The 
Table 3. The effect of stocking rate and year on the above-ground net primary production (ANPP) on the Desert Steppe in Inner Mongolia.

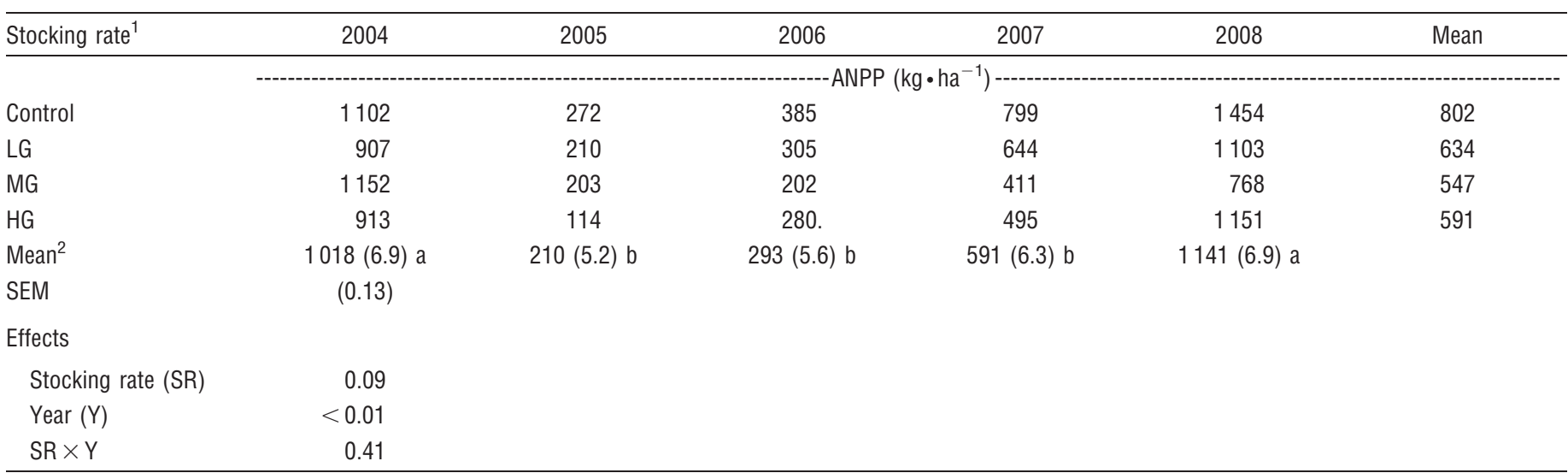

${ }^{1} \mathrm{LG}, \mathrm{MG}$, and HG represent low, moderate, and heavy stocking rates, respectively.

${ }^{2}$ Means of the year effect are given as the arithmetic with (log transformed); log transformed means that have the same letter are not different $(P>0.05)$.

total annual precipitation in $2004(253 \mathrm{~mm})$ and 2008 (231 $\mathrm{mm})$ was above the 5-yr (2004-2008) average $(193 \mathrm{~mm}$; Table 1).

\section{Forage Availability}

The initial vegetative conditions among planned stocking rate treatments were similar $(P>0.05)$ for ANPP, ground cover, and the proportion of grass in ANPP (Table 2). The initial weight of sheep assigned to each treatment in any year was similar $(P>0.05)$.

ANPP was affected $(P<0.05)$ by experimental year but not by the grazing treatment or its interaction with year (Table 3 ). ANPP was highly responsive to total precipitation over the period from April to July (Fig. 1); however, that relationship was not affected by the stocking rate treatments (for the LG, $\mathrm{MG}$, and $\mathrm{HG}$ treatments the intercepts were $-4,-38$, and $-25 \mathrm{~kg} \cdot \mathrm{ha}^{-1}[P=0.06]$ respectively, and the regression coefficients were $0.66,0.92$, and $0.86 \mathrm{~kg} \cdot \mathrm{ha}^{-1}$ ANPP $\cdot \mathrm{mm}$ precipitation $^{-1}[P=0.24]$, respectively).

The ADG of sheep for the summer, fall, or both periods combined was affected $(P<0.05)$ by both the planned stocking rate treatments and the experimental year, but not $(P>0.05)$ by their interaction (Table 4$). A D G$ was ranked $(\mathrm{LG}=\mathrm{MG})$ $>\mathrm{HG}$ for the summer period, $(\mathrm{LG}>\mathrm{MG})=\mathrm{HG}$ for the fall period, and $\mathrm{LG}>\mathrm{MG}>\mathrm{HG}$ for both periods combined.

\section{Effect of Stocking Rate on Sheep Live Weight Gain}

Over both summer and fall grazing periods, live weight gains per animal decreased linearly $(P>0.05)$ with increased stocking rate (Fig. 2). This relationship produced the maximum gains per ha at the highest stocking rate of about 2.4 SE ha ${ }^{-1}$. In the summer, ADG exhibited a plateau, defined by a log function $(P<0.05)$, until a stocking rate of about $1 \mathrm{SEha}^{-1}$ was reached (Fig. 2). The calculated gain per ha peaked near

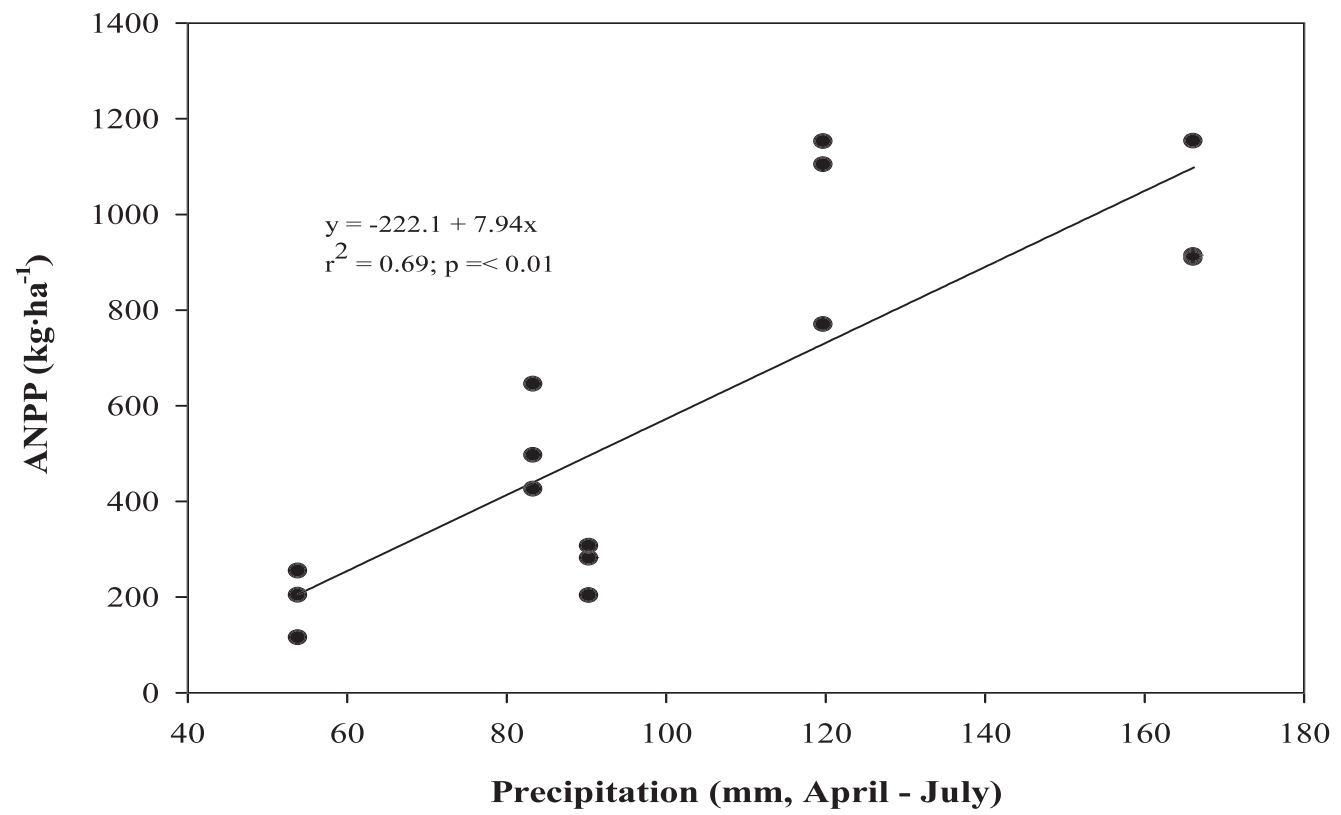

Figure 1. The effect of total precipitation from April to July over $5 \mathrm{yr}$ on annual net primary production (ANPP) on the Desert Steppe in Inner Mongolia. 
Table 4. Effect of planned stock rates and year on the average daily gain of sheep over the grazing season in the Desert Steppe of Inner Mongolia.

\begin{tabular}{|c|c|c|c|c|c|c|c|c|}
\hline Effect & Probability & $\begin{array}{l}\text { Stocking } \\
\text { rate }(\mathrm{SR})^{1,2}\end{array}$ & 2004 & 2005 & 2006 & 2007 & 2008 & Mean $^{2}$ \\
\hline & & & - & ---------- & rage daily & $\cdot h^{-1} \cdot c$ & -------- & ----------- \\
\hline \multicolumn{9}{|l|}{ Summer/fall } \\
\hline SR & $<0.01$ & $L G$ & 0.070 & 0.118 & 0.121 & 0.118 & 0.078 & $0.101 \mathrm{c}$ \\
\hline Year $(\mathrm{Y})$ & $<0.01$ & $M G$ & 0.061 & 0.102 & 0.100 & 0.094 & 0.085 & 0.088 b \\
\hline \multirow[t]{3}{*}{$S R \times Y$} & 0.13 & $H G$ & 0.042 & 0.062 & 0.067 & 0.059 & 0.066 & $0.059 \mathrm{a}$ \\
\hline & & Mean & $0.058 \mathrm{a}$ & $0.094 \mathrm{c}$ & $0.096 \mathrm{C}$ & $0.090 \mathrm{c}$ & 0.076 b & \\
\hline & & SEM & 0.0042 & 0.0049 & 0.0059 & 0.0042 & 0.0042 & \\
\hline \multicolumn{9}{|l|}{ Summer } \\
\hline SR & $<0.01$ & $L G$ & 0.091 & 0.118 & - & 0.107 & 0.101 & $0.104 \mathrm{~b}$ \\
\hline Year $(\mathrm{Y})$ & 0.02 & $M G$ & 0.085 & 0.102 & - & 0.101 & 0.119 & $0.102 \mathrm{~b}$ \\
\hline \multirow[t]{3}{*}{$\mathrm{SR} \times \mathrm{Y}$} & 0.17 & $H G$ & 0.060 & 0.062 & - & 0.076 & 0.079 & $0.069 \mathrm{a}$ \\
\hline & & Mean & $0.079 \mathrm{a}$ & $0.094 \mathrm{~b}$ & - & $0.095 \mathrm{~b}$ & $0.100 \mathrm{~b}$ & \\
\hline & & SEM & 0.0043 & 0.0046 & - & 0.0040 & 0.0040 & \\
\hline \multicolumn{9}{|l|}{ Fall } \\
\hline SR & 0.03 & $L G$ & -0.014 & - & - & 0.138 & 0.021 & $0.048 \mathrm{~b}$ \\
\hline Year (Y) & $<0.01$ & $M G$ & -0.036 & - & - & 0.079 & 0.001 & $0.015 \mathrm{a}$ \\
\hline \multirow[t]{3}{*}{$\mathrm{SR} \times \mathrm{Y}$} & 0.06 & $H G$ & 0.011 & - & - & 0.029 & 0.032 & $0.024 a b$ \\
\hline & & Mean & $-0.010 \mathrm{a}$ & - & - & $0.082 \mathrm{c}$ & $0.018 \mathrm{~b}$ & \\
\hline & & SEM & 0.0106 & - & - & 0.0106 & 0.0106 & \\
\hline
\end{tabular}

${ }^{1} \mathrm{LG}, \mathrm{MG}$, and $\mathrm{HG}$ represents the low, moderate, and heavy stocking rates, respectively.

${ }^{2}$ Means in a row or column having the same letter are not different $(P>0.05)$.

$2 \mathrm{SE} \mathrm{ha} \mathrm{a}^{-1}$. In the fall, gains were marginally affected $(P=0.06)$ in an inverse quadratic function, suggesting that gains were greatest at a light stocking rate but near zero over most of the range of rates that were investigated (Fig. 2). The gains per ha followed a similar trend.

Live weight gains followed an exponential relationship to allowable forage with a plateau near $0.1 \mathrm{~kg} \cdot \mathrm{ha}^{-1} \cdot \mathrm{d}^{-1}$ (Fig. 3). This level was reached when the allowable forage per sheep equivalent was near $3 \mathrm{~kg} \cdot \mathrm{SE}^{-1} \cdot \mathrm{d}^{-1}$.

\section{DISCUSSION}

Heavy grazing pressure on the Desert Steppe had no effect on forage production over a 5-yr period, and rainfall had a similar effect in all grazing treatments regardless of grazing pressure. The primary factor affecting livestock performance was the biomass of forage allocated to animals over the grazing period, which was influenced by high variation in the amount of annual rainfall. Therefore, production on the Desert Steppe conforms to the disequilibrium theory of grassland stability, which is defined largely by climate (Fernandez-Gimenez and Allen-Diaz 1999), and the recommended stocking rate could be dictated by animal performance (Jones and Sandland 1974).

This suggests that stocking rate should be adjusted annually to utilize forage at a rate that would maximize livestock productivity. However, this is difficult to achieve because most herders do not have the capacity to remove and replace animals to achieve fluctuating targets, and those targets cannot be predicted early enough to be effective. Therefore, the grazing recommendations made by Martin (1975) for systems with high rainfall variability were for constant stocking at $90 \%$ of average annual capacity. This rate was expected to return greater profits than flexible stocking (Martin 1975).

Based on our study, maximum animal performance was achieved when sheep were offered at least $3 \mathrm{~kg}$ forage dry matter per day over the grazing season. For a 5-mo (155-d) grazing period, this would require about $465 \mathrm{~kg}$ dry matter $\cdot \mathrm{ha}^{-1} \cdot \mathrm{SE}^{-1}$, which was achieved in only 2 of the $5 \mathrm{yr}$, suggesting that 1 sheep per ha was too high. This observation is supported by results showing a loss of animal weight with stocking rates greater than 0.5 sheep per ha when estimated for the entire grazing season. However, this estimate is not expressed over the summer period when animal losses were not evident until after 1 sheep per ha.

Nevertheless, over $5 \mathrm{yr}$ of the study, most live weight gains per ha were produced where the stocking rate was stocked from 1.5 to 2 (or more) sheep per ha. Although the maximum gains may be obtained at higher stocking rates, those animals would have lower body fat and need to be fed more preserved forage in the winter to maintain their condition (Freeze and Willms 1998). This factor was not part of the study but might be expected where weight gains are suppressed by inadequate nutrition. Therefore, maximum economic output over the $5 \mathrm{yr}$ of the study would likely be derived at a rate that is substantially lower than the maximum live weight gains per ha.

An important consideration in the development of a recommended stocking rate for the Desert Steppe is the requirement for stability in livestock numbers and the ability of the herder to stock at rates that avoid periodic livestock losses and grassland deterioration (Martin 1975). This strategy is based on managing the grassland for average productivity and, for the Desert Steppe, an average utilization rate varying from $30 \%$ to $50 \%$ (Zhixin and Shuyou 1989) for winter 


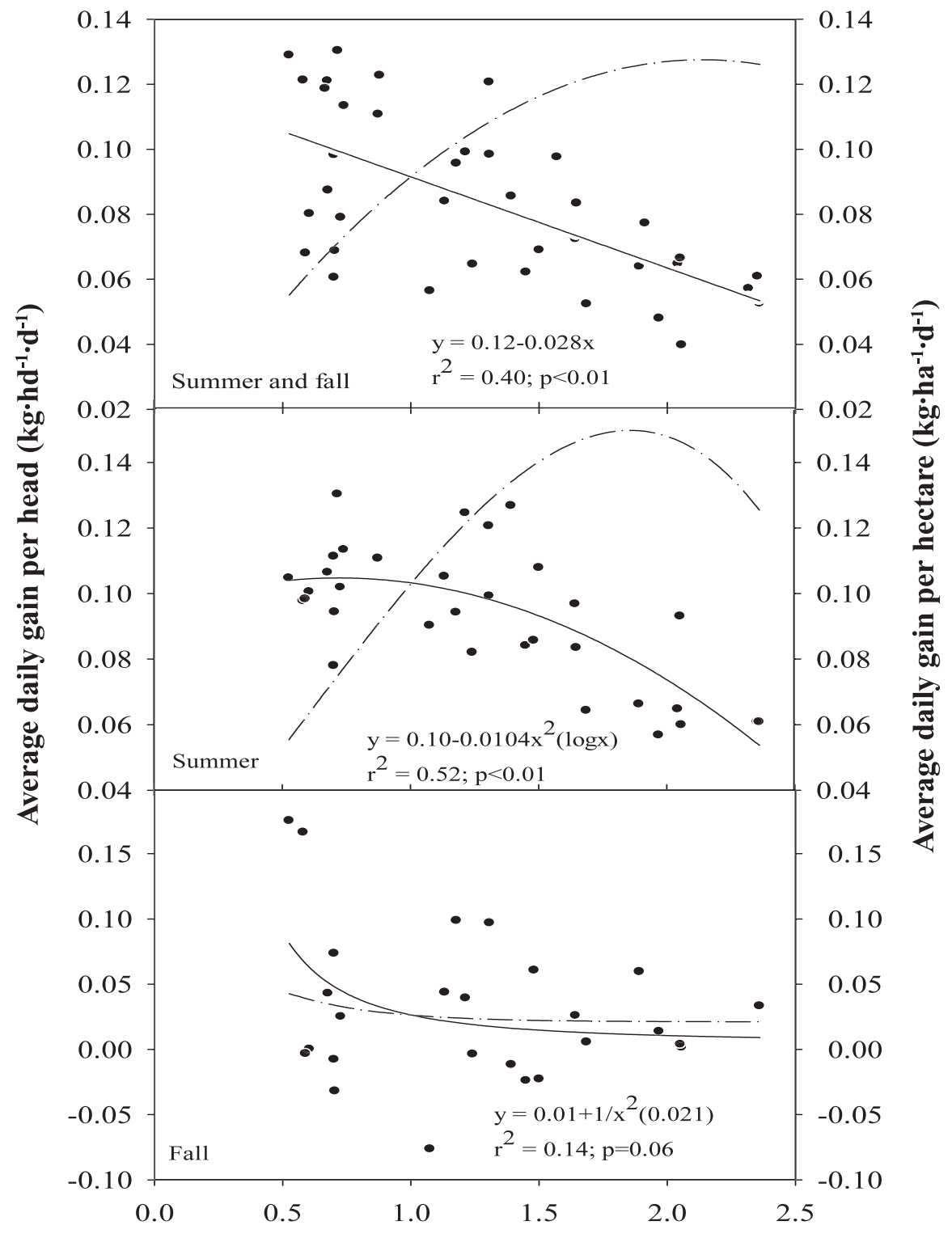

Stocking rate (sheep equivalent $\left.\cdot h \mathrm{a}^{-1}\right)$

Figure 2. Average daily gain of sheep relative to stocking rates adjusted annually in each paddock according to a 50-kg sheep-equivalent animal at the time grazing was initiated in spring.

grazing. For summer grazing, the utilization rate would probably be set at the more conservative rate of $30 \%$. Given these constraints, and an average production of $640 \mathrm{~kg} \cdot \mathrm{ha}^{-1}$, the proper stocking rate on the Desert Steppe over a 5-mo grazing period should be about $0.41 \mathrm{SE} \mathrm{ha}^{-1}$. This value is calculated as: $\left(640 \mathrm{~kg} \cdot \mathrm{ha}^{-1} \times 30 \%\right) /\left(3 \mathrm{~kg} \cdot \mathrm{SE} \cdot \mathrm{d}^{-1} \times 155 \mathrm{~d}\right)$ and may be adjusted by the nutritive requirements of a particular class of animal or the ability of the grassland to sustain heavier utilization. For example, according to the National Research Council (1985) requirements for a 50-kg ewe in late stage of gestation (assuming this is equivalent to a $50 \mathrm{~kg}$ whether that is expected to gain $0.1 \mathrm{~kg} \cdot \mathrm{d}^{-1}$ ) is about $1.6 \mathrm{~kg} \cdot \mathrm{d}^{-1}$, suggesting that an average ANPP utilized at $30 \%$ could support $0.77 \mathrm{SE} \cdot \mathrm{ha}^{-1}$. This stocking rate is still well within the mass required to achieve maximum weight per individual animal ( $3 \mathrm{~kg} \cdot \mathrm{d}^{-1}$ or $465 \mathrm{~kg}$ over 5 mo of grazing).
Nevertheless, these values are much lower than that reported from an earlier study that recommended almost 2 sheep $\cdot \mathrm{ha}^{-1}$ over the same period (Han et al. 2000) as this study. It is possible that our estimates reflect the continuous overgrazing in recent years that has likely resulted in significant decreases in carrying capacity across the region.

The trends in animal weight gain relative to stocking rate were dependent on the period of investigation and, presumably, our lowest stocking rates. The trend we observed over the summer was similar to that reported by Hart et al. (1988a) for cattle in the mixed grass prairie. However, for the entire grazing period, which was similar to that of Hart et al. (1988a), the plateau at the lower stocking rates was not evident but was modified into a linear downward trend when the fall observations were included, similar to those of Harlan (1958), Phillips and Coleman (1995), and Ackerman et al. 


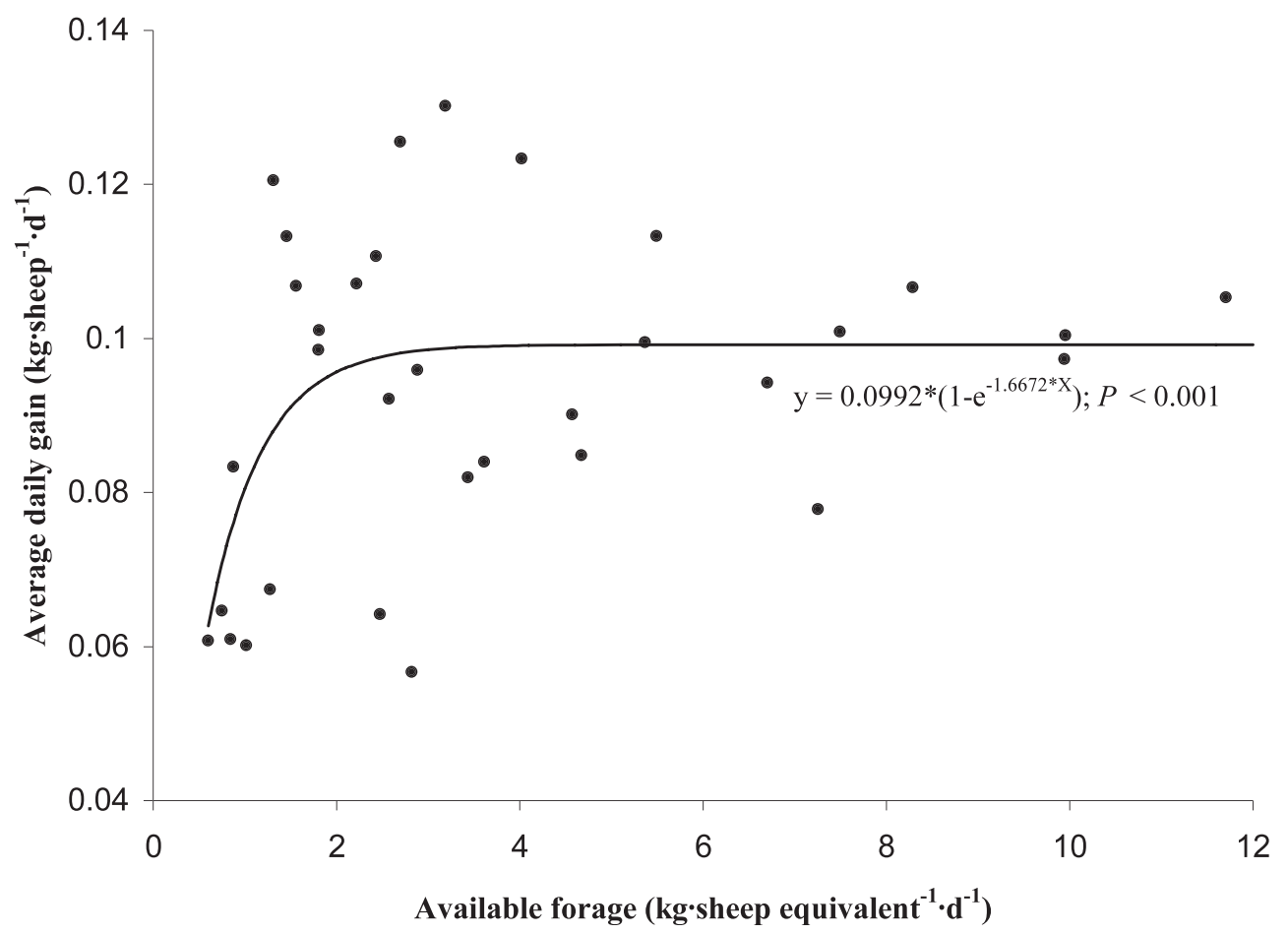

Figure 3. The effect of allowable forage for sheep on their average daily gain on the Desert Steppe in Inner Mongolia over the combined summer and fall grazing seasons.

(2001). In the fall, sheep responded positively to a very low stocking rate, which was reflected in the trend for the total grazing season. Therefore, it appears that in the fall, low stocking rates enable selective grazing that result in better nutrition and improved weight gains. Presumably, a plateau would be evident below the stocking rates we observed.

The vegetation of the Desert Steppe is resistant to change and the $5 \mathrm{yr}$ of the study are too short to have produced a new equilibrium of vegetation characteristics within each treatment. While ANPP was not affected by the grazing treatment, forage quality appeared to be altered by shifts in the proportions of grass, pasture sage (Artemisia frigida Willd.), and Russian thistle (Salsola collina Pall.) among the grazing treatments. We observed a large biomass of Russian thistle in the heavily stocked treatment in 2008, which was a wet year, and the lowest mass of pasture sage in the heavily stocked treatment in the last $2 \mathrm{yr}$ of the trial (Han Guodong and Wang Zhongwu; personal communication, February 2009). The relatively short period of the study leaves us with no clear evidence that the lightly stocked treatment was recovering from overgrazing before the trial began. However, the trends we observed in the proportions of Russian thistle and pasture sage suggest that the heavy stocking rate was causing further degradation.

\section{MANAGEMENT IMPLICATIONS}

The Desert Steppe needs to be managed conservatively to achieve production stability because of the large annual variation in rainfall, which is linked with large fluctuations in ANPP. High ANPP in years of high precipitation are obtained from annual species, which have little or no value for winter grazing and provides no value for carryover to the following year. Therefore, basing the carrying capacity on an average ANPP can be misleading in managing for long-term stability, and a better estimate would be to base it on carrying capacity from the production of perennial species. We estimated two stocking rates based on different assumptions of forage requirements for each $\mathrm{SE}$. Our maximum recommended stocking rate of $0.77 \mathrm{SE} \cdot \mathrm{ha}^{-1}$ for a 5 -mo grazing period is equivalent to our lowest experimental rate of approximately $0.75 \mathrm{SE} \cdot \mathrm{ha}^{-1}$ and is based on a relatively short-term assessment of this grassland type. The study needs to progress for a longer period to validate this estimate and ascertain the process of grazing induced degradation in the Desert Steppe. In the meantime, herders need to follow a conservative stocking rate to ensure livestock production can be sustained and that grassland degradation does not continue.

\section{ACKNOWLEDGMENTS}

We acknowledge David Kemp's helpful suggestions for the revised manuscript. Special thanks are expressed to all of the students that helped to collect samples in the field and conducted laboratory analyses.

\section{LITERATURE CITED}

Ackerman, C. J., H. T. Purvis, G. W. Horn, S. I. Paisley, R. R. Reuter, and T. N. Bodine. 2001. Performance of light vs heavy steers grazing Plains Old World bluestem at three stocking rates. Journal of Animal Science 79:493-499.

Ash, A. J., AND D. M. Stafford Smith. 1996. Evaluating stocking rate impacts in rangelands: animals don't practice what we preach. Rangeland Journal 18:216-243.

Bates, J. D., T. Svejcar, R. F. Miller, and R. A. Angell. 2006. The effects of precipitation timing on sagebrush steppe vegetation. Journal of Arid Environments 64:670-697. 
Common, T. G., E. A. Hunter, J. Eadie, M. J. S. Floates, and J. Hodgson. 1993. The long-term effects of a range of pasture treatments applied to three seminatural hill grassland communities. 2. Animal performance. Grass Forage Science 46:253-263.

Derner, J. D., and R. H. HaRt. 2005. Heifer performance under two stocking rates on fourwing saltbush-dominated rangeland. Rangeland Ecology \& Management 58:489-494.

Fernandez-Gimenez, M. E., and B. Allen-Diaz. 1999. Testing a non-equilibrium model of rangeland vegetation dynamics in Mongolia. Journal of Applied Ecology 36:871-885.

Freeze, B., AND W. Willms. 1998. Economics of maintaining cow on fescue prairie in winter. Journal Range Management 52:113-119.

Fynn, R. W. S., AND T. G. O'Connor. 2000. Effect of stocking rate and rainfall on rangeland dynamics and cattle performance in a semi-arid savanna, South Africa. Journal of Applied Ecology 37:491-507.

Han, G., B. LI, Z. Wel, AND H. LI. 2000. Liveweight change of sheep under 5 stocking rate in Stipa breviflora Desert Steppe. Grassland of China 1:4-6, 38.

HarLan, J. R. 1958. Generalized curves for gain per head and gain per acre in rates of grazing studies. Journal of Range Management 11:140-147.

Hart, R. H., and M. M. Ashby. 1998. Grazing intensities, vegetation, and heifer gains: 55 years on shortgrass. Journal of Range Management 51:392-398.

Hart, R. H., M. J. Samuel, P. S. Test, and M. A. Smith. 1988a. Cattle, vegetation, and economic responses to grazing systems and grazing pressure. Journal of Range Management 41:282-286.

Hart, R. H., J. W. Waggoner JR., T. G. Dunn, C. C. Kaltenbach, and L. D. Adams. $1988 \mathrm{~b}$. Optimal stocking rate for cow-calf enterprises on native range and complementary improved pastures. Journal of Range Management 41:435-441.

Hatch, G. P., and N. M. Tainton. 1997. The influence of stocking rate, range condition and rainfall on seasonal beef production patterns in the semiarid savanna of Kwazulu-Natal. South African Journal of Animal Science 27:50-54.

Jones, R. J., And R. L. SAndLAnd. 1974. The relation between animal gain and stocking rate: derivation of the relation from the results of grazing trials. Journal of Agricultural Science 83:335-342.

Martin, S. C. 1975. Stocking strategies and net cattle sales on semidesert range. Fort Collins, C0, USA: US Department of Agriculture Forest Service, Rocky
Mountain Forest and Range Experiment Station. U.S. Department of Agriculture Forest Service Research Paper RM-146. 10 p.

McCollum, T., III. 1993. Managing stocking rates to achieve livestock production goals in North Texas and Okalahoma. In: J. R. Cox and J. F. Cadenhead [EDs.]. Proceedings of Symposia, Department of Rangeland Ecology Management, Texas Agricultural Extension Service and Texas A \& M University College Station, Texas. 29-40.

Milchunas, D. G., J. R. Forwood, and W. K. Lauenroth. 1994. Productivity of longterm grazing treatments in response to seasonal precipitation. Journal of Range Management 47:133-139.

National Research Council. 1985. Nutrient requirements of sheep. Washington, DC, USA: National Academy Press. $99 \mathrm{p}$.

ORR, D. M. 1980. Effects of Sheep Grazing Astrebla Grassland in central western Queensland. II. Effects of seasonal rainfall. Australian Journal of Agricultural Research 31:807-820.

ORR, R. J., AND J. E. Newton. 1984. The effect of stocking rate on a lamb production system with February-lambing ewes. Grass Forage Science 39:27-34.

Phillips, W. A., and S. W. Coleman. 1995. Productivity and economic return of three warm season grass stocker systems for the southern Great Plains. Journal of Production Agriculture 8:334-339.

SAS Institute [COMPUTER SOFTWARE]. 2008. SAS OnlineDoc ${ }^{\circledR}$ 9.1.3. Cary, NC, USA: SAS Institute Inc.

SYSTAT Software Inc. [COMPUTER SOFtware]. 2008. TableCurve 2D 5.01. SYSTAT Software Inc.

URSINO, N., AND S. ContaRINI. 2006. Stability of banded vegetation patterns under seasonal rainfall and limited soil moisture storage capacity. Advances in Water Resources 29:1556-1564.

WiLson, A. D., AND N. D. MACLEOD. 1991. Overgrazing: present or absent? Journal of Range Management 44:475-482.

Yu, M., J. E. EluIs, and H. E. Epstein. 2004. Regional analysis of climate, primary production, and livestock density in Inner Mongolia. Journal of Environmental Quality 33:1675-1681.

ZhIXIN, X., and L. Shuyou. 1989. Effect of winter utilization rate on vegetative characteristics of Desert Steppe. Journal of Inner Mongolia Grassland 12:27-33. 